\title{
ИССЛЕДОВАНИЕ ЦИФРОВОГО УПРАВЛЕНИЯ БИБЛИОТЕКОЙ В ВУЗАХ НА ФОНЕ БОЛЬШИХ ДАННЫХ
}

\section{RESEARCH ON THE MANAGEMENT OF ELECTRONIC LIBRARIES IN HIGHER EDUCATION INSTITUTIONS WITH BIG DATA}

Li Shaojie

Summary: The article is devoted to the analysis of library services for readers in higher education institutions using information technologies. The relevance of the work is due to the interest of students in remote work with catalogues of library systems, as well as the interest of researchers in the possibility of improving the work of libraries. The main problem of the research is the library's working hours coinciding with the student's training, as well as the inability to work with electronic publications in a convenient access for readers. We come to the conclusion that University libraries need digital management.

Keywords: library, digital library management in universities, electronic library system.

\author{
Ли Шаоцзе \\ Цзилиньский педагогический университет \\ 49829623@q9.com
}

Аннотация: Статья посвящена анализу библиотечного обслуживания читателей в вузах с использованием информационных технологий. Актуальность работы обусловлена интересом студентов к удаленной работе с каталогами библиотечных систем, а также интересу исследователей к возможности совершенствования работы библиотек. Главной проблемой исследования является время работы библиотеки, совпадающее с обучением студентов, а также невозможность работать с электронными и оцифрованными изданиями в удобном для потенциальных читателей доступе. Мы приходим к выводу, что библиотеки вузов нуждаются в цифровом управлении.

Ключевые слова: библиотека, цифровое управление библиотекой в вузах, электронная библиотечная система.
$\mathrm{C}$ оздание цифровых библиотек в высших учебных заведениях требует изменения привычного функционирования библиотек, расширения должностных обязанностей работников, модернизации комплектования фонда, а также возможности цифрового управления всей системой.

Актуальность работы обусловлена интересом потенциальных читателей к изменению работы библиотечной системы, а также ученых к разработке исследуемой проблемы. В качестве примера можно привести работы С.Г. Смолиной [6], С.К. Канн [2], Савицкой М.Т. [5] и др. исследователей. Ученые отмечают важность создания единой образовательной платформы в условиях вуза, формирования сетевой библиотеки с ограниченным доступом для обучающихся образовательных организаций.

Следует подчеркнуть, что в современном образовательном пространстве библиотека является неотъемлемой частью среды, направленной на формирование кадрового потенциала для цифровой среды. Необходимо отметить «Концепцию Базовой модели компетенций цифровой экономики», в которой указана роль библиотеки современного вуза: направленность на образование как процесс повышения компетенций обучающихся, способствующий непрерывному личностному развитию в течение всей жизни [3, с. 6].
Для работы с большими данными, включающими в себя учебные и методические пособия, классическую и отраслевую литературу, научные работы (кандидатские и докторские диссертации, авторефераты аспирантов и преподавателей, защитившихся на базе соответствующего университета), научные журналы, необходимо создание электронно-библиотечной системы университета. Всю литературу, имеющуюся в библиотеке необходимо классифицировать по тематическим и целевым признакам, которые будут способствовать поиску документов и работе с ними. Можно выделить следующие разделы: собственной регенерации; удаленного доступа, используемые на лицензионной основе, а также удаленные ресурсы открытого доступа.

Данная ЭБС должна соответствовать всем требованиям федерального государственного образовательного стандарта высшего профессионального образования нового поколения. При этом оцифрованные издания не должны нарушать главу 70 Гражданского кодекса РФ «Авторское право» [1].

Помимо этих ресурсов каждая университетская библиотека может использовать в работе современные российские ЭБС: «КнигаФонд», «Университетская библиотека онлайн», «Лань», «Контекстум» и др. Указанные ЭБС являются для университета платными платформами, каждая из которых не может удовлетворять 
требованиям вузовской библиотеки в полной форме. В качестве примера можно привести лицензионные нормативы, в которых указано, что в библиотеке вуза должно быть представлено не менее 25 издательств [4].

Следующей возможностью цифрового управления библиотекой вуза является создание сетевой библиотеки. Это направление предполагает объединение электронного каталога библиотеки вуза и глобальной сети «Интернет». На практике это можно реализовать следующим образом: на сайте библиотеки обучающиеся и преподаватели находят необходимую литературу и с помощью гиперссылки переходят на полную версию текста, официально размещенного в сети «Интернет». Этой практикой уже пользуются зарубежные и отечественные платформы:Web of Science, Science, Direct, РИНЦ, др. При создании сетевой библиотеки также можно делать ссылки на доступные вузу электронные библиотечные системы.

Следует отметить возможность цифрового управления библиотекой вуза с помощью обращения к фонду Федеральной государственной информационной системы «Национальная электронная библиотека» (НЭБ). Ресурсы этой библиотеки включают в себя уникальные книги, монографии, учебные пособия, конспекты лекций, диссертации и авторефераты, которые востребованы студенческой аудиторией и профессорскопреподавательским составом. Кроме этого, мы можем отметить интерес молодежи к правовым базам данных, поэтому для создания современной университетской библиотеки необходимо получить доступ к сайту «Консультант Плюс», на котором представлены основные законодательные акты и Кодексы Российской Федерации в новой редакции.

Следует отметить возможность использования цифровой библиотекой сайта ЛитРес. Этот сайт представляет собой библиотеку электронных книг. Он является крупнейшим в России и странах СНГ представителем рынка электронных и аудиокниг. Библиотека вуза может использовать данный сайт для предоставления обучающимся права чтения бесплатных книг в режиме онлайн на платформе ЛитРес, а также платных изданий, которые официально закуплены библиотекой вуза.

Таким образом, для создания цифрового управления библиотекой в вузах с большими данными необходимо создать сетевую библиотеку. Для создания сетевой библиотеки необходимо обращение к электронно-библиотечным системам, таким как «Лань», «Университетская библиотека онлайн» и др. Самыми востребованными в студенческой и профессорско-преподавательской среде являются электронные библиотеки ЛитРес и НЭБ, поскольку в них представлены уникальные научные издания, монографии, диссертации и авторефераты научных исследований.

Кроме этого, хочется отметить, что для создания успешного цифрового управления библиотекой необходимо постоянно пополнять книжный фонд и электронный каталог, который требует общедоступности для обучающихся и преподавателей вуза, возможно, с платным контентом.

Все указанные требования к цифровому управлению библиотекой в вузах предполагают повышение требований к компетенциям библиотечных кадров, которым необходимо не только профессионально подбирать учебные пособия, быть профессиональными консультантами в проблемах чтения и специализированной литературы, но также владеть современными цифровыми технологиями, научиться находить необходимую для обучающихся и профессорско-преподавательского состава информацию. Данные квалификационные требования предполагают профессиональное становление и обучение библиотечных кадров в течение всей жизни.

\section{ЛИТЕРАТУРА}

1. Авторское право // Гражданский кодекс Российской Федерации (часть четвертая) от 18.07.2019 № 230-Ф3. - Гл. 70 [Электронный ресурс]. Режим доступа: http://www.consultant.ru/document/cons_doc_LAW_64629/0b318126c43879a845405f1fb1f4342f473a1eda/ Дата обращения: 14.04.2020.

2. Канн С.К. У истоков композитных библиотек будущего // Вестник научных конференций. - 2016. - № 9-4 (13). - С. $49-50$.

3. Концепция Базовой модели компетенций цифровой экономики / А.Я. Данилюк, А.М. Кондаков. - М.: РудН, 2018. - 23 с.

4. Печатные и электронные образовательные и информационные ресурсы // Федеральный закон «0б образовании» от 29.12.2012 № 273-Ф3 (ред. от 01.03.2020). - Ст. 18 [Электронный ресурс]. Режим доступа: http://www.consultant.ru/document/cons_doc_LAW_140174/30db2837641cc729b1d5e2eee7 f0f7982722cfac/ Дата обращения: 14.04.2020.

5. Савицкая М.Т. Электронная библиотечная система в библиотеке аграрного вуза: проблемы выбора // Вестник Российского государственного аграрного заочного университета. - 2012. - № 12 (17). - С. 10-13.

6. Смолина С.Г. Развитие информационной компетенции обучающихся в условиях вузовской библиотеки: Дис. кандидата пед. н. - Челябинск, 2016. - 184 с. 